\title{
SUNFLOWER COMMERCIAL HYBRID YANA, DEVELOPED WITH MUTANT RESTORER LINE R 12003
}

Encheva, J. ${ }^{*}$, Shindrova, P., Encheva, V. and Penchev, E.

Dobroudja Agricultural Institute, General Toshevo 9520, Bulgaria

Received: March 15, 2012

Accepted: June 10, 2012

\author{
SUMMARY
}

Hybrid Yana was developed with simple cross of Bulgarian line cms2607 and mutant line R12003. Mutant line was produced after treatment of immature sunflower (Helianthus annuus L.) zygotic embryos of fertility restorer line R 2574 with ultrasound. In 2004, 2006 and 2007 years hybrid Yana was presented for testing at State Variety Testing Commission. The hybrid considerably exceeded the mean standard (the Bulgarian commercial hybrid Albena and French commercial hybrid Diabolo) by seed yield. The seed yield of hybrid Yana was significantly higher with $31 \mathrm{~kg} / \mathrm{dka}$, or $9.8 \%$. The correlations of the cross cms $2607 \times \mathrm{R} 12003$ with the mean values of the parental lines (h1) and with the mean value of the parent with higher indices (h2) were statistically significant. In $\mathrm{h} 1$ the variation was from $152.4 \%$ to $1471.2 \%$; in $\mathrm{h} 2$ the variation was within 149.5-1052.9\%. The evaluation of the heterosis effect parameters proved that the parent with the higher values of the indices was superdominant. This was markedly expressed for indices total seeds number per head and seed yield per head. Hybrid Yana possessing immunity to the Orobanche cumana population of races A-F and immunity to Plasmopara helianhi-races 300,700 and 731 .

Key words: Helianthus annuus, ultrasound, mutant line, combining ability, hybrid, heterosis, resistance, Plasmopara helianhi, Phomopsis helianthi, Phoma macdonaldii, Orobanche cumana

\section{INTRODUCTION}

Developing highly productive sunflower varieties is a priority of modern breeding. The realization of their production potential depends directly on their resistance to diseases and pests and on their adaptability to changeable environments.

Worldwide there are hybrids tolerant or resistant to the economically important diseases on sunflower and the parasite Orobanche (Škorić, 1985); they, however,

* Corresponding author: 
HELIA, 35, Nr. 56, p.p. 47-60, (2012)

quickly drop out of national production lists due to the occurrence of new more virulent races which impose the necessity of new resistant varieties and hybrids.

Sunflower is a crop of high risk due to losses caused by diseases. Under conditions favorable for development of the fungal pathogens causing downy mildew (Plasmopara helianthi), phoma (Phoma macdonaldii), phomopsis (Phomopsis helianthi), sclerotinia (Sclerotinia sclerotiorum) and the parasite Orobanche (Orobanche cummana), the crop may be entirely compromised.

There are two ways of overcoming this problem: a chemical approach and a breeding-genetic approach. The breeding-genetic approach improves the environment and is at the same time effort-saving. It has been demonstrated that it is the most efficient means for control of fungal diseases.

Downy mildew caused by Plasmopara halstedii Farl. Berlese et de Toni is one of the economically most important diseases which can lead to significant losses in sunflower production. During the recent years, rapid changes in the physiological specialization of the pathogen occurred. The fungus is forming new more virulent races which are overcoming the resistance of the varieties and hybrids used in mass production (Mouzeyar et al., 1994; Viranyi and Gulya, 1996; Shindrova, 2005; Shindrova, 2010). According to other researchers these races are resistant to the fungicides applied in production (Viranyi et al., 1992). Therefore there is a clear and present danger of epiphytoty of this disease and of subsequent significant losses for sunflower production.

The situation with broomrape is similar. The changes in the varietals structure during the last years and in the agronomy practices of sunflower cultivation created favorable conditions for propagation and rapid distribution of this parasite in Bulgaria. As a result it is expanding to new territories and the percent and rate of attack have increased. Significant changes occurred in the broomrape population as well: it enriched with new races of greater virulence (Shindrova, 1994; Shindrova, 2006). Similar processes are observed in other countries as well - Turkey, Romania, Spain, etc. (Pacurenu-Joita et al., 1998, Kaya et al., 2004; FernandezMartinez et al., 2000). This situation requires searching for means of disease control and diminishing the losses they cause.

Target-oriented breeding work on sunflower is based on the production potential and adaptability with a view of its seed production. This leads to development of a crop with lower genetic variability and narrowing of the heritability basis of the new varieties. Improvement of plasticity and richer genetic potential can be achieved through gene mutations and recombination. Encheva et al. (2003a, 2008a,b) and Encheva, 2009 reported the development of sunflower lines resistant to diseases and Orobanche through the embryoculture method in combination with ultrasonic.

Positive results were obtained when induced mutagenesis and tissue cultivation were combined appropriately in tomato (Gavazi et al., 1987), in maize, banana and plantain (Novak et al., 1988, 1990), potato (Ahloowalia, 1990), wheat (Cheng et al., 
1990), oil crops (Ashri, 1993), in rice (Maluszynski et al., 1994) and other crops (Mike et al., 1990).

Of all methods recommended for control of diseases and broomrape on sunflower, the breeding method is the most efficient and economically most advantageous. The developing of resistant hybrids and their introduction in practice will lead to restricted propagation and distribution of the pathogens, and in the course of time - to cleaning of the infected fields.

The aim of this study was:

a) investigation on some agronomical traits of hybrid Yana at State Variety Testing Commission and

b) to evaluate hybrid Yana for resistance to Phoma, Phomopsis, Downy mildew and parasite Broomrape.

\section{MATERIAL AND METHODS}

A part of the experiments were carried out at the trial field of State Variety Testing Commission, and another under laboratory conditions.

\section{Developing of mutant line}

The Bulgarian fertility restorer line $\mathrm{R} 2574$, witch is highly homozygtic, was used as donor material. A main requirement to the initial plant material used according to the methods of embryo culture in combination with ultrasound is to be genetically pure, i.e., homozygotic to the highest possible degree. Therefore the control line R 2574 with very good morphological uniformity due to long selfing (over 30 generations) was chosen as initial material for induced mutagenesis.

Plants were grown in the field and were hand-pollinated. Immature zygotic embryos (11-13 days old) were aseptically isolated and sterilized under the following conditions: 1) $1 \mathrm{~min}$ in $95 \%$ ethanol; 2) $15 \mathrm{~min}$ in bleaching solution $(2.7 \% \mathrm{Cl})$; 3 ), followed by several washings with sterile distilled water. Sixty zygotic embryos were plated for each variant.

The isolated immature zygotic embryos were treated with ultrasound at dose $25.5 \mathrm{~W} / \mathrm{cm}^{2}$ for $1 \mathrm{~min}$ before plating on nutrition medium $\mathrm{M}$ for further growing (Azpiroz et al,.1988): 1/2 MS (Murashige \& Skoog, 1962) macro salts, MS micro salts, B5 vitamins (Gamborg et al., 1968), $20 \mathrm{~g} / \mathrm{l}$ sucrose, pH-5.7. The conditions for cultivation were: $25^{\circ} \mathrm{C}, 16 / 8 \mathrm{~h}$ photoperiod for one week. The embryo culture method allows isolation of embryos before terminating their development and their plating onto nutrition medium to grow in vitro seedlings. The plants which formed roots were transferred to soil and were further grown and self-pollinated under greenhouse conditions. 


\section{Field experiments}

As a result from long-term selfing and individual selection, new sunflower line was produced in R9 generation. The main criterion for selection was resistance to Orobanche cumana.

\section{Hybridization}

To determine the combining ability of the new developed sunflower mutant line R 12003, the sterile analogue of the Bulgarian selfed line 2607 was used. The standards for comparing the new hybrid Yana developed were the Bulgarian commercial hybrid Perfect and French hybrid Diabolo.

The obtained hybrid was tested for three years 2004, 2006 and 2007 at the breeding fields of State Variety Testing Commission according to the block-design method, in three replications, the area of each replication being $25 \mathrm{~m}^{2}$.

\section{Biometric evaluation of hybrid Yana}

The biometric evaluation and biochemical analysis of hybrid Yana was made on 10 plants for each individual year, and included main agronomic traits as seed yield, 1000 seed weight, oil in the kernel (\%), plant height, head diameter, days to flowering and days to maturity. 1000 seed weight (g) was determined on three samples of 50 seeds per head each.

Heterosis effect was calculated for plant height, diameter of head, total seed number per head, 1000 seed weight, mean value of seed yield per head.

\section{Biochemical analysis}

To determined the oil content of air-dry seeds from the materials included in the study, Nuclear-magnetic resonance (Newport Instruments Ltd., 1972) was used.

\section{Phytopatological evaluation}

The phytopathological evaluation of hybrid Yana was performed with regard to the local Orobanche population and the diseases phomopsis, phoma and downy mildew at the Sunflower Phytopathology Laboratory and infection fields of DAI General Toshevo.

The evaluation for resistance to downy mildew and broomrape were done according to standard methodologies (Panchenko, 1973; Gulya et al., 1991). The phytopathological evaluation of hybrid was performed with regard to downy mildew Plasmopara halstedii (Farl.) Berlese \& de Toni-race 300, 700, 731 and to the local Orobanche population (race A-F) at the Sunflower Phytopathology Laboratory during 2007.

With a view to characterizing the resistance to downy mildew were used the method suggesting by Gulya et al. (1991). The evaluation of 50 plants from hybrid was carried out using standard methodologies: $0 \%=\mathrm{S}$ (sensitive); $100 \%=\mathrm{R}$ (resistant). 
Broomrape resistance was evaluated under greenhouse conditions according to Panchenko (1975), slightly modified to local conditions. Broomrape resistance was calculated as percentage of non-infected plants. The reaction of 50 plants from each hybrid was recorded using the following scale: $0-100 \%$.

The evaluation for resistance to attacks of grey spots (Phomopsis helianthi) and black spots (Phoma macdonaldii) was performed in filed and in artificial infection plots. The type and severity of the attack were read one week after mass flowering according to the following scales:

Type of grey spot attack:

0 - no symptoms;

1 - a necrotic lesion up to $5 \mathrm{~cm}$ in diameter;

2 - a necrotic lesion over $5 \mathrm{~cm}$ in diameter;

3 - several merged necrotic lesions on the stem;

4 - a stem broken at the place of infection.

Type of black spot attack:

0 - no symptoms;

1 - a necrotic lesion near the petiole;

2 - several necrotic lesions on the stem;

3 - the entire stem is covered with necrotic lesion or the stem is broken.

Attacking rate: what portion of the plant's stem is covered with lesions of the pathogen (1/3, 2/3 or 3/3) (Encheva and Kiryakov, 2000).

\section{Statistical analysis}

The developed new hybrid Yana were analyzed statistically with regard to the agronomic traits such as seed yield, 1000 seed weight, oil in the kernel, plant height, head diameter, days to flowering and days to maturity.

Analysis of the experimental data was by the statistical package BIOSTAST 6.0.

The means of parents and cross according to the investigated indices, such as plant height, head diameter, 1000 seed weight, total seed number per head, seed yield per head, mean errors and reliability intervals were calculated.

The coefficients of heterosis effect $\mathrm{h} 1$ and $\mathrm{h} 2$, on which the evaluation of the cross relative to the parents by the above indices was based, were also calculated.

The data were analyzed using the statistical package SPSS Version 17.0.

\section{RESULTS AND DISCUSION}

The aim of this study was to investigate some agronomic traits of hybrid Yana and to evaluate it for resistance to phoma, phomopsis, downy mildew and parasite broomrape. The hybrid was developed with mutant restorer line R 12003 (Figure 2).

The farther line R 12003 was produced by treatment with ultrasound of immature zygotic embryos and in combination with embryo culture method at initial genotype R 2574. Line R 12003 possessed mutation for resistance to Orobanche cumana. The initial genotype R 2574 was susceptible to broomrape. 
To determine the combining ability of the new developed sunflower line $\mathrm{R}$ 12003, the sterile analogue of the Bulgarian selfed line 2607 (Figure 1) was used. Sterile line was developed at the base of cytoplasm Pet 1.
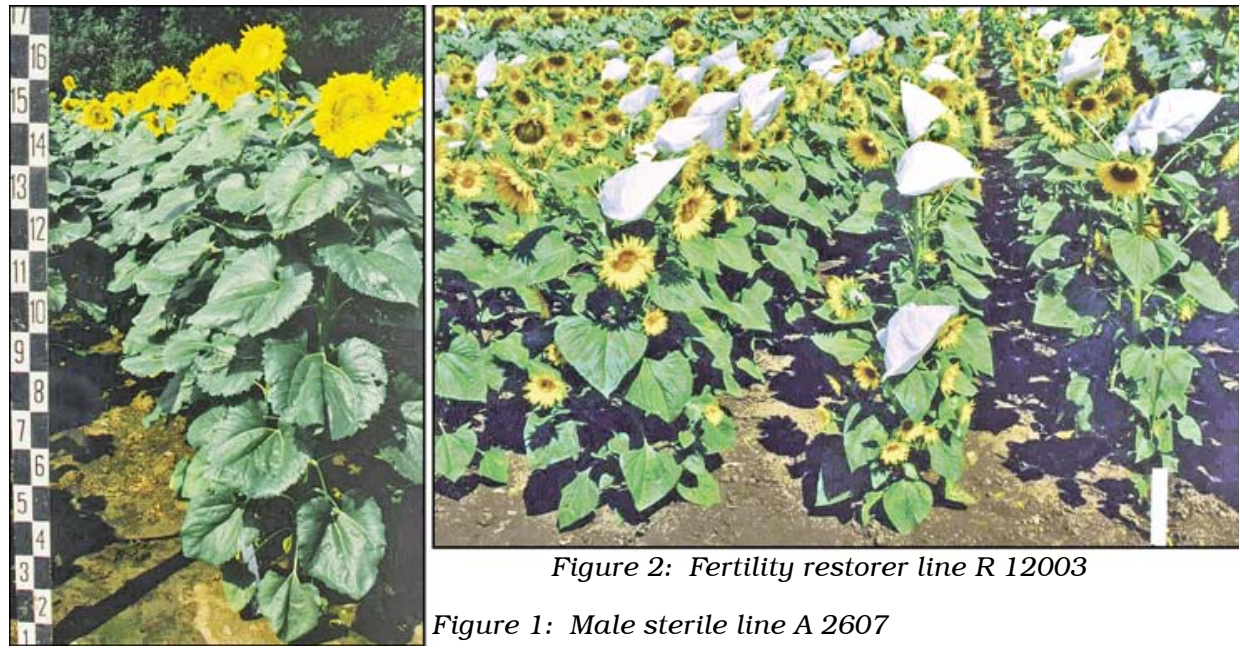

Figure 2: Fertility restorer line $R 12003$

Figure 1: Male sterile line A 2607

\section{Study on the production potential and biological characteristics of hybrid Yana developed with the participation of mutant line R 12003.}

The 3 years testing of line R 12003 showed 100\% restoration ability and very good combining ability. The sterile analogue of the Bulgarian selfed line A 2607 was used for a tester. A two factor dispersion analysis of hybrid Yana-Figure 3 (simple cross ms2607 $\times \mathrm{R} 12003$ ) was carried out with regard to the main indices seed yield (kg/dka) and 1000 seed weight $(\mathrm{g})$.

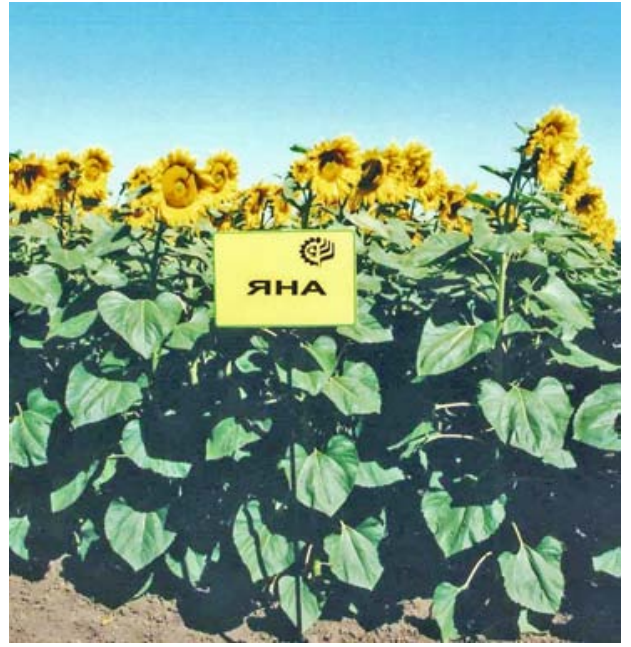

Figure 3: Hybrid Yana developed by the cross A $2607 \times R 12003$.

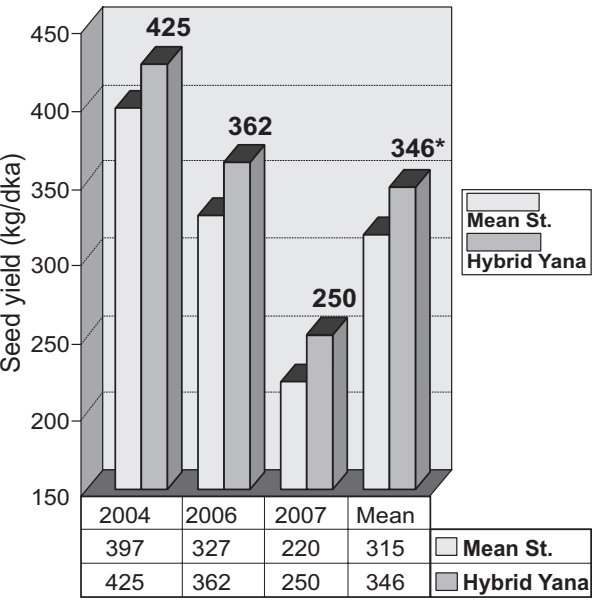

Figure 4: Seed yield of hybrid Yana and mean standard Perfect and Diabolo during 2004, 2006 and 2007 years $\left({ }^{*}-P=5 \%\right)$. 
In 2004, 2006 and 2007 years hybrid Yana was presented for testing at State Variety Testing Commission (in 7 different regions). The hybrid considerably exceeded the mean standard (the Bulgarian commercial hybrid Perfect and French

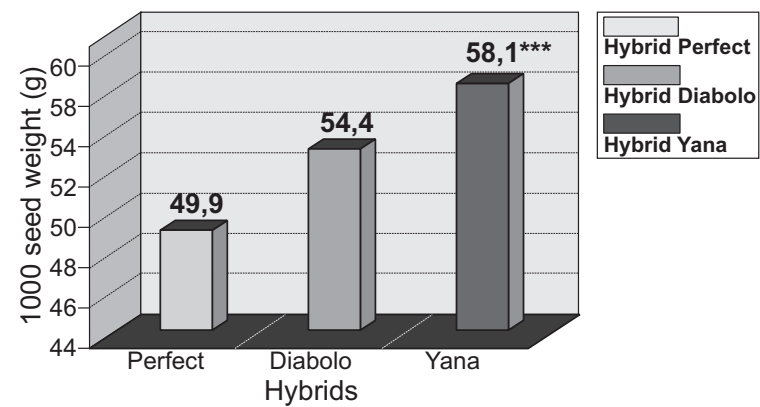

Figure 5: 1000 seed weight of standard Perfect, standard Diabolo and new hybrid Yana, harvest year 2006. commercial hybrid Diabolo) by seed yield. The seed yield of hybrid Yana was significantly higher with $31 \mathrm{~kg} / \mathrm{dka}$, or $9.8 \%$ (Figure 4 ).

The 1000 seed weight exceeded the mean value of standard Perfect by $8.2 \mathrm{~g}$, which is highly significant (Figure 5). The observed difference at plant height was in direction towards decrease (Table 1). The hybrid Yana possessed plant height with $15.4 \mathrm{~cm}$, less than the standard Perfect. This considerable positive difference is of important value for mechanize harvesting of the hybrid.

Table 1: Characteristics of hybrid Yana and standards-commercial hybrids Perfect and Diabolo. Harvest years 2006, average data

\begin{tabular}{lcccc}
\hline Traits & $\begin{array}{c}\text { Standard } \\
\text { hybrid Diabolo }\end{array}$ & $\begin{array}{c}\text { Standard } \\
\text { hybrid Perfect }\end{array}$ & Hybrid Yana & LSD \\
\hline Plant height (cm) & $156.81 \mathrm{~d}$ & $174.13 \mathrm{a}$ & $158.71 \mathrm{~d}$ & Gd 5\%=20.85 \\
Diameter of head (cm) & $17.97 \mathrm{~b}$ & $17.98 \mathrm{~d}$ & $16.87 \mathrm{~d}$ & Gd 5\%=1.25 \\
1000 seeds weight $(\mathrm{g})$ & $54.35 \mathrm{~d}$ & $49.93 \mathrm{c}$ & $58.09 \mathrm{~d}$ & Gd $5 \%=5.31$ \\
Oil in the kernel (\%) & $50.94 \mathrm{c}$ & $47.49 \mathrm{c}$ & 46.00 & Gd 5\%=0.66 \\
Days to flowering (no) & $68.00 \mathrm{~b}$ & $66.00 \mathrm{a}$ & 64.00 & Gd 5\%=1.66 \\
Days to maturity (no) & $122.00 \mathrm{~b}$ & $119.00 \mathrm{~d}$ & $118.0 \mathrm{~d}$ & Gd 5\%=3.76 \\
\hline
\end{tabular}

Values with the same letter is not significant at the level of $P=5 \%$

\section{Heterosis for agronomically important traits}

Table 2 presents the mean values of the indices of parents and cross, as well as he the mean value error. According to all indices, the cross A $2607 \times \mathrm{R} 12003$ exceeded both parents, especially by total number of seeds, 1000 kernel weight and seed yield: for these indices the values were several times higher than the respective values for the parental lines.

Table 2: Mean values of plan height, diameter of head, total seed number per head, 1000 seed weight and mean value of seed yield per head of parents and the cross $(2607 \mathrm{~A} \times \mathrm{R}$ 12003-hybrid Yana).

\begin{tabular}{lccc}
\hline & $2607 \mathrm{~A}$ & $12003 \mathrm{R}$ & $2607 \mathrm{~A} \times 12003 \mathrm{R}$ \\
\cline { 2 - 4 } Plant height $(\mathrm{cm})$ & $121.1 \pm 1.1$ & $116.5 \pm 1.7$ & $181 \pm 1.8$ \\
Diameter of head $(\mathrm{cm})$ & $13.8 \pm 0.3$ & $9.4 \pm 0.3$ & $23.3 \pm 0.6$ \\
Total seed number per head (no) & $131.9 \pm 18.6$ & $38.1 \pm 6.6$ & $745.1 \pm 120.1$ \\
1000 seed weight $(\mathrm{g})$ & $31.4 \pm 2.2$ & $42.8 \pm 1.4$ & $68.2 \pm 4.1$ \\
Mean value of seed yield per head $(\mathrm{g})$ & $5.1 \pm 0.8$ & $2.2 \pm 0.3$ & $53.7 \pm 7.7$ \\
\hline
\end{tabular}


This fact was also confirmed when evaluating the coefficients of heterosis effect h1 and h2 (Table 3). The correlations of the cross with the mean values of the parental lines (h1) and with the mean value of the parent with higher indices (h2) were statistically significant.

Table 3: Heterosis for plant height, diameter per head, total seed number per head, 1000 seed weight and seed yield per head relative to parental mean (h1) and better parent (h2)

\begin{tabular}{lcc}
\hline & $\mathrm{h} 1$ & $\mathrm{~h} 2$ \\
\cline { 2 - 3 } Plant height $(\mathrm{cm})$ & $152,4 * \star$ & $149.46 * *$ \\
Diameter of head $(\mathrm{cm})$ & $200,86 * \star$ & $168.84 * *$ \\
Total seed number per head $(\mathrm{no})$ & $876,6 * \star \star$ & $564.9 * \star *$ \\
1000 seed weight $(\mathrm{g})$ & $183,82 * \star$ & $159,34 * *$ \\
Seed yield per head $(\mathrm{g})$ & $1471,2 * \star *$ & $1052.9 * * *$ \\
\hline
\end{tabular}

** - statisticaly significant $p=0.01 ; * * *$ - statisticaly significant $p=0.001$

In $\mathrm{h} 1$ the variation was from $152.4 \%$ to $1471.2 \%$; in $\mathrm{h} 2$ the variation was within 149.5-1052.9\%. The evaluation of the heterosis effect parameters proved that the parent with the higher values of the indices was superdominant. This was markedly expressed for indices total seeds number per head and seed yield per head.

\section{Characteristics of hybrid Yana.}

Plant height of a hybrid Yana is from 136.0 to $170.8 \mathrm{~cm}$. Lodging or breaking of the head at maturity is not observed. Average number of leaves on the main stem. The hybrid is without branches and lateral branches are not formed at maturity. Leaves are average size, hart shaped and green. Leaf blistering is week. Fineness of serration is fine. The angle of lateral veins is right or almost right. Concave leaf shape of cross section. Leaf wings absent. Ray flowers oval and orange. Yellow disk flowers. Anthocyanin coloration is absent. Presence of pollen. Bracts are green and rounded. Turned position of a head at maturity. Convex head-shape at the seed side. Seed-shape is black, ovoid-elongated and with gray stripes. The position of the stripes is both marginal and lateral.

\section{Evaluation of mutant line R 12003 and hybrid Yana for resistance to some economically important diseases and parasite on sunflower}

In most countries where sunflowers grow commercially successful production is endangered by many fungal pathogens and parasites. Losses may be severe, near $100 \%$ parts or even entire fields under extreme circumstances (Škorić, 1994).

The parasitic phanerogame Orobanche cumana grow on sunflower roots, resulting in weak and dwindled plants, with thin steam. The parasite enhances the transpiration of damaged plants, which in drought conditions are withering, even if attacked by a small number of parasitic plants (Iliescu et al., 1998). Broomrape presents serious problems to sunflower production in Bulgaria, as well (Shindrova, 1994). 
Hence, there is a need for greater variability providing additional sources of resistance to diseases, and insects, and seed quality characteristics among modern cultivated sunflower (Seiler, 1992). At present cultivated hybrid sunflower utilizes an extremely narrow genetic base, mainly the male sterile sytoplasm derived from the wild species $H$. petiolaris (Leclercq, 1969). Genetic variability, as resistance to parasite Orobanche cumana in particular may be increase using induced mutagenesis (Encheva et al., 2008a).

In our study except the established morphological and biometrical changes a mutation was observed in the reaction of the genotypes towards Orobanche cumana parasite. The initial genotype R 2574 was susceptible to broomrape. The mutant line R12003 showed 100\% resistance to the local broomrape population. These results were confirmed during several years of evaluation. On the basis of these data the conclusion was drawn that the resistance of the new line was due to the mutagenic treatment with ultrasound. This result confirmed our previous investigation with ultrasound (Encheva et al., 2008a, 2008b).

The results allow us to presume that the resistance of the mutant sunflower line to Orobanche cumana occurred as a result from a single gene dominant mutation. Similar conclusion has been made by Christov et al., 1996, analyzing the type of resistance to broomrape of mutant sunflower forms obtained through irradiation of air dry seeds with gamma rays. The authors found out that it was controlled by a single dominant gene. The dominant resistant gene mutants were obtained after EMS treatment of pollen of tomato (Gavazi et al., 1987).

Many studies at classical breeding programme at sunflower show a monogenic control by a single dominant gene over sunflower resistance against races $\mathrm{A}$ to $\mathrm{E}$ (Ish-Shalom-Gordon et al., 1993; Sukno et al., 1999) and although two dominant genes (Dominguez, 1996b).

In nature, mostly the polyploidy perennial species are considered sources of resistance. Among them, H. tuberosus has been most frequently used as a source of resistance to Orobanche (Pustovoit, 1978; Christov, 1996). Nikolova et al., 1998, observed a high degree of resistance to the local Orobanche population in the wild species H. divaricatus (M-015), H. giganteus (M-011), H. glaucophyllus (M-12), H. grosseserratus (M-014), H. mollis (M-082), H. nuttallii (M-088), H. smithii (M-008). In hybridization of $100 \%$ resistant wild species with cultural sunflower, they observed variation in the resistance of the hybrid materials from 10 to $100 \%$.

The race $F$ resistant population $B R 4$, derived from wild species, was found to be under the control of a single dominant gene designated $\mathrm{Or}_{6}$ (Perez-Vich et al., 2002). Pacureanu et al. (2004) reported also a single dominant gene controlling the resistance to race $\mathrm{F}$ in Romania.

In our experiment we prove that $100 \%$ stable resistance of the sunflower mutant line to the local Orobanche population can also be obtained through induced mutagenesis. The same mutation as resistance to the parasite broomrape, was obtained in all variants of treatment with ultrasound. This suggests that the 
same mutable regions were affected in sunflower genome during in vitro treatment with mutagens.

Combining induced mutagenesis in immature sunflower zygotic embryo with the embryo culture method, it can be assumed that the new variability obtained is due only to the effect of the mutagen. This assumption is confirmed by the fact that the embryo culture method alone does not generate variation due to the lack of mutagen factors in the nutrition medium and the short period of in vitro cultivation of the immature zygotic embryos.

A study was carried on the hybrid Yana for resistance to the diseases Phomopsis helianthi, Phoma macdonaldii, Plasmopara helianthi and the parasite Orobanche cumana (Table 4).

Table 4: Evaluation of standards-commercial hybrids Diabolo and Perfect and new hybrid Yana for resistance to phoma, phomopsis, downy mildew and parasite broomrape (2007, \%).

\begin{tabular}{|c|c|c|c|c|c|c|c|c|}
\hline \multirow{4}{*}{ Hybrid } & \multicolumn{2}{|c|}{$\begin{array}{c}\text { Phomopsis } \\
\text { helianthi }\end{array}$} & \multicolumn{2}{|c|}{$\begin{array}{c}\text { Phoma } \\
\text { macdonaldi }\end{array}$} & \multicolumn{3}{|c|}{$\begin{array}{c}\text { Plasmopara } \\
\text { helianthi }\end{array}$} & \multirow{2}{*}{$\begin{array}{c}\text { Orobanche } \\
\text { cumana } \\
\text { race } \\
\text { A-F }\end{array}$} \\
\hline & \multirow{3}{*}{$\begin{array}{c}\text { degree } \\
\text { of infection }\end{array}$} & \multirow{3}{*}{ type } & \multirow{3}{*}{$\begin{array}{c}\text { degree } \\
\text { of infection }\end{array}$} & \multirow{3}{*}{ type } & $\begin{array}{l}\text { race } \\
300\end{array}$ & $\begin{array}{l}\text { race } \\
700\end{array}$ & $\begin{array}{l}\text { race } \\
731\end{array}$ & \\
\hline & & & & & Resistance & Resistance & Resistance & Resistance \\
\hline & & & & & $\%$ & $\%$ & $\%$ & $\%$ \\
\hline Standard Diabolo & $2 / 3$ & 2 & $1 / 3$ & 1 & 100.0 & 95.0 & 100 & 100.0 \\
\hline Standard Perfect & $1 / 3$ & 1 & $1 / 3$ & 1 & 90.5 & 84.5 & 90.0 & 100.0 \\
\hline Hybrid Yana & $1 / 3$ & 1 & $1 / 3$ & 1 & 100.0 & 100.0 & 100.0 & 100.0 \\
\hline
\end{tabular}

The hybrid Yana was characterized with immunity to the parasite Orobanche cumana-race A-F. That immunity was inherited from the mutant restorer line $\mathrm{R}$ 12003.

The new hybrid was immune to the Plasmopara helianthi-race 300 and 700. The last data showed $100 \%$ resistance to the new race 731 , also. Hybrid Yana carry resistance to Plasmopara helianthi, inherited from the Bulgarian mother line of the hybrid (A 2607). While the standard Perfect possessed resistance to downy mildew at the range from $84.05 \%$ to $90.5 \%$, second standard Diabolo showed resistance from $95.0 \%$ to $100.0 \%$.

The response of the hybrids to grey and black spot attack is given in Table 4, also. Hybrid Yana demonstrated resistance to the attack of both phoma and phomopsis. At the same time the standard Diabolo showed lesions typical for the two pathogens covering $2 / 3$ of the stems (grey spots) and 1/3 of the stems (black spots).

Resistance of hybrid Yana to some economically important diseases and parasite Orobanche are a guarantee that it is suitable for mass production. 


\section{CONCLUSION}

We succeed to create mutant sunflower line with positive changes as resistance to parasite Orobanche cumana population of races A-F. A mutant line R 12003 was created at initial susceptible genotype R 2574. Mutation was induced after treatment of immature sunflower (Helianthus annuus L.) zygotic embryos of fertility restorer line R 2574 with ultrasound.

The available literature on sunflower does not provide data on treatment of immature zygotic embryos with ultrasound. In this respect the approach is especially valuable due to the fact that immature sunflower zygotic embryos are treated at an earl stage of development, i.e., this is functional tissue. Our results confirmed the conclusion of Skirvin, 1978, that mutagenesis physical or chemical, is favorable for induction of mutations in tissue cultures. It was established that the possibilities of experimental mutagenesis in using embryos at an early stage of their development are greater, as compared to air dry seeds (Atanassov, 1988). Although induced mutagenesis is a random and unpredictable process, it is an invaluable fact that the occurred mutation of resistance to the parasite broomrape is of stable inheritance in the progenies of the fertility restorer line.

Hybrid Yana was developed with simple cross of Bulgarian line cms2607 and mutant line R 12003. During three years tasting at State Variety Testing Commission hybrid Yana considerably exceeded the mean standard (the Bulgarian commercial hybrid Albena and French commercial hybrid Diabolo) by seed yield. The hybrid simultaneously possessing immunity to the Orobanche cumana population of races A-F and immunity to Plasmopara helianthi-races 300, 700 and 731 .

Hybrid Yana was successfully used for seed production at Bulgaria and Romania.

\section{REFERENCES}

Панченко, А.Я., 1975. Вестник семьскохозяйственной науки № 2.

Ahloowalia, B.S., 1990. In vitro radiation induced mutagenesis in potato. In: Sangwan, R.S. and Sangwan-Norreel, R.S., (Eds). The Impact Biotechnology in Agriculture. Kluwer Academic Publisher, Dordrecht, pp. 39-46.

Ashri, A., 1993. Mutation breeding in oil crops. In: Maluszynski, M. and Ashri (Eds). Report of the First FAO/IAEA Seminar on the use of Induced Mutagenesis and related Biotechnology for Crop Improvement for the Middle East and the Mediterranean region. IAEA, Vienna, pp. 82-94.

Cheng, X.Y., Gao, M.W., Ling, Z.Q. and Lin, K.Z., 1990. Effect of mutagenic treatments on somaclonal variation in wheat (Triticum aestivum L.). Plant Breeding 105: 47-52.

Christov, M., 1996. Characterization of wild Helianthus spices as sources of features for sunflower breeding. In: Calgari, P.D.S. and Hind, D.J.N. (Eds). Composite: Biology and Utilization. Proceedings of the International Composite Conference, Kew, 1994. (Hind D.J.N., Editor-in-Chief), Royal Botanical Gardens, Kew, 2: 547-570.

Dominguez, J., 1996. R-41, a sunflower restorer inbred line, carrying two genes for resistance against a highly virulent Spanish population of Orobanche cernua. Plant Breed. 115: 203-204. 
Encheva, V. and Kirykov, I., 2000. A method for evaluation of sunflower resistance to Diaporthe/ Phomopsis helianthi Munt.-Cvet. et al. Bulgarian Journal of Agricultural Science 8: 219 222.

Encheva, J., Kohler, H., Friedt, W., Tsvetkova, F., Ivanov, P., Encheva, V. and Shindrova, P., 2003. Field evaluation of somaclonal variation in sunflower (Helianthus annuus L.) and its application for crop improvement. Euphytica 130: 167-175.

Encheva, J., Shindrova, P. and Penchev, E., 2008a. Developing mutant sunflower lines (Helianthus annuus L.) through induced mutagenesis. Helia 31(48): 61-72.

Encheva, J., Christov, M. and Shindrova, P., 2008b. Developing mutant sunflower lines (Helianthus annuus L.) by combined used of classical method with induced mutagenesis and embryo culture method. B.J.A.S. 14(4): 397-404.

Encheva, J., 2009. Sunflower (Helianthus annuus L.) mutant line, developed using induced mutagenesis. In: Breeding and Technical Crops, Field Crop Studies Vol.V(1): 109-117.

Fernandez-Martinez, J.M., Melero-Vara, J., Munoz-Ruiz, J., Ruso, J. and Domingez, J., 2000. Selection of wild and cultivated sunflower for resistance to a new broomrape race that overcomes resistance of the $\mathrm{Or}_{5}$ gene. Crop Science 40(2): 550-555.

Kaya, Y., Demerci, M., Evci, G., 2004. Sunflower (Helianthus annuus L.) breeding in Turkey for broomrape (Orobanche cernua Loeffl.) and herbicide resistance. Helia 27(40): 199210 .

Leclercq, P., 1969. Une sterilite male chez le tournesol [A male sterility in sunflower]. Annales d' Amelioration des Plantes 19: 99-106.

Maluszynski, M., Amano, E., Ahloowalia, B., Van Zanten, L. and Sigurbjornsson, B., 1994. Mutation techniques and related biotechnologies for rice improvement. In: $7^{\text {th }}$ Meeting of the International Program on Rice Biotechnology, May 1994, Bali, The Rockefeller Foundation, New York. p. 294.

Mather, K., 1949. Biometrical genetics. London. Pp. 137-157.

Marinković, R., Dozet, B., Vasić, D., 2003. Oplemenjivanje suncokreta (Monografija), Školska knjiga, Novi Sad, pp.190-210.

Micke, A., Donini, B. and Maluszynski, M., 1990. Induced mutation for crop improvement. Mutat. Breed. Rev. 7: 1-41.

Newport Instrument Ltd., 1972. Use of the Newport quantity analyzer as a replacement for solvent extraction for measuring the oil and fat content of oil seeds, chocolate, meat and other materials. Newport Pagnell, England.

Nikolova, L., Christov, M. and Shindrova, P., 1998. New sunflower forms, resistant to Orobanche cumana Wallr., originating from interspecific hybridization. Proceedings of Fourth International Orobanche Workshop. September 23-26, Albena, Bulgaria.

Novak, F.J., Daskalov, S., Brunner, H., Nestincky, M., Afza, R., Dolezelova, M., Lucretti, S., Herichova, A. and Hermelin, T., 1988. Somatic embryogenesis in maize and comparison of genetic variability induced by gamma radiation and tissue culture techniques. Plant Breeding 101: 66-79.

Novak, F.J., Afza, R., van Duren, M. and Omar, M.S., 1990. Mutation induction by gamma irradiation of in vitro cultured shoot-tips of banana and plantain (Musa cvs). Trop. Agric. 67(1): 21-28.

Pacureanu-Joita, M., Vranceanu, A.V., Soare, G., Marinescu, A. and Sandu, I., 1998. The evaluation of the parasite-host intraction system [Helianthus annuus L.]-[Orobanche cumana Wallr.] in Romania. Proceedings of $2^{\text {nd }}$ Balk. Symposium on Field Crops. 16-20 June, 1998. Novi Sad, Yugoslavia. Pp. 153-155.

Pacureanu, M., Veronesi, C., Raranciuc, S. and Stanciu, D., 2004. Parasite-host plant interaction of Orobanche cumana Wallr. (Orobanche cernua Loefl.) with Helianthus annuus. In: Seiler, G.J. (Ed), Proc. 16 ${ }^{\text {th }}$ Int. Sunf. Conf., Fargo, ND, August 29-September 2, 2004. Int. Sunflower Assoc., Paris. Pp. 171-177.

Panchenko, A.N., 1973. Ranniya diagnostika zarazihoustoychivosti pri selekcii podsolnecnika. Zbirnik VNIIMK, pp. 107-115.

Perez-Vich, B., Akhtouch, B., Munoz-Ruz, J., Fernandez-Martinez, J.M. and Jan, C.C., 2002. Inheritance of resistance to a highly virulent race " $F$ " of Orobanche cumana Wallr. in sunflower line derived from interspecific amphiploids. Helia 25: 137-144.

Pustovoit, G.V. and Skuropat, Z.J., 1978. The inheritance in wild species of genus Helianthus (In Russian). Zbornik-VNIMK Pest and diseases of oil crops, Krasnodar. Pp. 44-48. 
Tahir, M., Sagadat, H. N., Sajid Bashir, H. A., 2002. Correlation and path coefficient analysis of morphological traits in sunflower (Helianthus annuus L.). Int. J. Agric. Biol. 4(3): 341343.

Gavazzi, G., Tonelli, C., Todesco, G., Arreghini, E., Raffaldi, F., Vecchio, F., Barbuzzi, G., Biasini, M. and Sala, F. 1987. Somaclonal variation versus chemically induced mutagenesis in tomato (Licopersicum esculentum L.). Theor. Appl. Genet. 74: 733-738.

Gulya, T.J., Miler, J.F., Firanyi, F. and Sackston, W.E., 1991. Proposed internationally standardized method for race identification of Plasmopara halstedii. Helia 14: 11-20.

Iliescu, H.C., Iordache, E., Jinga, V. and Ionita, A., 1998. Response of some sunflower hybrids to attack of the parasitic phanerogame Orobanche cumana Wallr. In: Current problems of Orobanche Researches, Proceedings of the Fourth International Workshop on Orobanche. K. Wegmann, K., L.J. Musselman, D.M. Joel, (Eds.) Albena, 23-26, September, Bulgaria, pp. 291-294.

Ish-Shalom-Gordon, N., Jacobsohn, R. and Cohen, Y., 1993. Inheritance of resistance to Orobanche cumana in sunflower. Phytopathol. 83: 1250-1252.

Mouzeyar, S., Philippon, J., Walser, P., Vear, F., Tourvieille de Labrouhe, D., 1994. Sunflower resistance to French races of downy mildew (Plasmopara halstedii). Agronomie 14: 335336.

Seiler, G.J., 1992. Utilization of wild sunflower species for the improvement of cultivated sunflower. Field Crop Research 30: 195-230.

Shindrova, P., 1994. Distribution and race complex of broomrape (Orobanche cumana Wallr.) in Bulgaria. Proceedings of the Third International Workshop on Orobanche and related Striga research, Amsterdam, pp.142-145.

Shindrova, P., 2005. New nomenclature of Downy Mildew Races in Sunflower Plasmopara halstedii (Farl. Berlese et de Toni ) in Bulgaria (Race composition during 2000-2003 ). Helia 28(42): pp. 57-64.

Shindrova, P., 2006. Broomrape (Orobanche cumana Wallr.) in Bulgaria - Distribution and race composition. Helia 29(44).

Shindrova, P., 2010. Investigation on the composition of Downy Mildew (Plasmopara halstedii (Farl. Berlese et de Toni) in Bulgaria during 2007-2008. Helia 33(52): 19-24.

Škorić, D., 1985. Sunflower breeding for resistance to Diaporthe (Phomopsis helianthi Munt.Cvet.). Helia FAO 8: 21-24.

Škorić, D., 1994. Sunflower breeding for resistance to dominant diseases. EUCARPIA-"Section oil and protein crops". Albena (Bulgaria), 22-24 October, pp. 28-30.

Sukno, S., Melero-Vara, J.M. and Fernandez-Martinez, J.M., 1999. Inheritance of resistance to Orobanche cumana Loefl. In sex sunflower lines. Crop Science 39: 674-678.

Viranyi, F., Gulya, T. and Maširević, S., 1992. Proceedings of the $13^{\text {th }}$ International Sunflower Conference, Vol. II, Pisa ( Italy ), 7-11 September.

Viranyi, F. and Gulya, T., 1996. Pathogenic variation in Plasmopara halstedii. Downy Mildew Newsletter, Number 9. 
